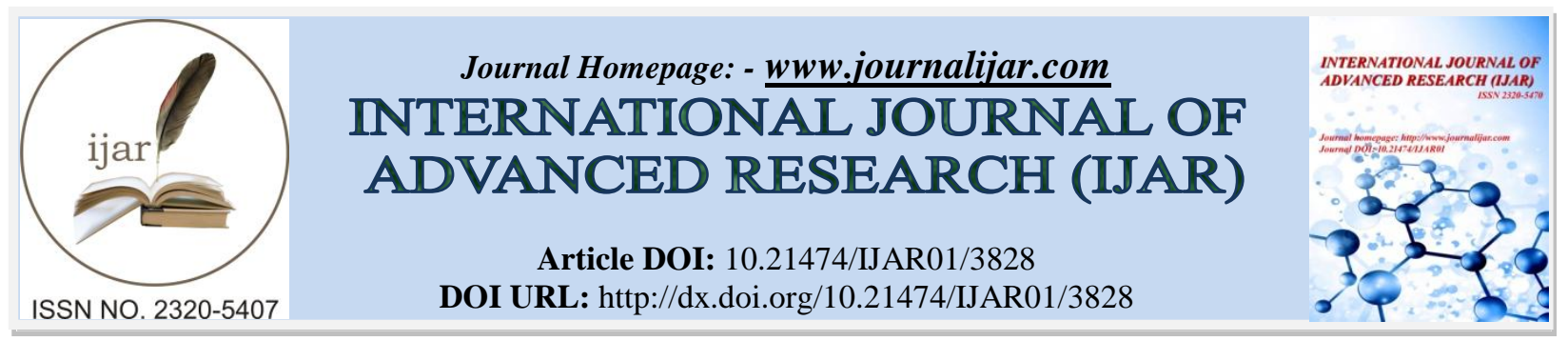

RESEARCH ARTICLE

\title{
AN OVERVIEW OF CORPORATE SOCIAL RESPONSIBILITY.
}

Saprem Shirvoikar ${ }^{1}$ and Satyam Shirvoiker ${ }^{2}$.

1. Assistant Professor of Law, Government College of Arts, Commerce and Science, Khondala, Marcel Goa.

2. Assistant Quality Assurance, Schiffer \& Menezes India Pvt Ltd, Verna, Goa.

\section{Manuscript Info}

Manuscript History

Received: 06 February 2017

Final Accepted: 08 March 2017

Published: April 2017

Key words:-

Corporate, CSR

\section{Abstract}

The present study is based on section 135 of companies Act 2013. This section explains the concept of Corporate Social Responsibility (CSR). The main highlight of the study is the companies which are coming under the CSR policy and what are penalties which are imposed on the companies which are providing wrong financial statement. The profit maximization is the ultimate goal of the company but this CSR policy imposes duty on the Corporate to work for the benefit of the society. This duty should be done by the Corporate sector not as the burden imposed by law but as a long term investment which will provide them benefit in the future.

Copy Right, IJAR, 2017,. All rights reserved.

\section{Introduction:-}

CSR is the Corporate Social Responsibility. Section 135 of the Companies Act 2013 gives brief description of Corporate Social Responsibility. Earning profit is the ultimate goal of carrying on a business, but the CSR policy imposes on every Corporate whose net worth is 500 crores and turnover of Rs 1000 crores and net profit of 5 crores or more shall constitute a Corporate Social Responsibility committee. Corporate sector requires capital, land and labour which are taken from the society. The Corporate sector should not only take from the society but also give in return to the society. By investing in CSR there will be bond between the Corporate and the society. If the Corporate sector only takes from the society then there will be imbalance in the society. The development of the society is not the ultimate goal of the government but also of the corporate sector by investing in CSR. There should be give and take relation between the Corporate and the society. The Corporate while investing in CSR has to think that they are investing in a long run and not the duty which is imposed by the law.

\section{Need of the Study:-}

To simplify section 135 of the Companies Act 2013.

\section{Methodology:-}

Secondary source of data which is by way of Referring text Books, Research Journals, etc.

Objective of the study:-

To study the Corporate Social Responsibility (CSR) Policy. 


\section{Key issues of CSR}

\section{Poverty Elimination:-}

Poverty is major issue of the country. The implementation of CSR policy makes it mandatory for Corporate to work for the elimination of poverty. Unemployment is one of the main reasons for poverty and by providing jobs to the locals the poverty can be reduced.

\section{Labour Rights:-}

The labours are the vulnerable and exploited group of the society. The rules and regulations put forth under the labour laws are partly followed in terms of wages, working period of hours, etc. Even an offence when committed such as child labour are not detected due to lack of knowledge, fear of undesired results, lack of employment opportunities etc.

\section{Human Rights:-}

Human rights are the basic natural rights inherent to all human beings without discrimination. These rights are sometimes violated such as remuneration, leisure time, equal pay for equal work, livelihood, education etc. Implementation of CSR makes these rights to be enjoyed by every person who is in relation to CSR.

\section{Environmental Condition:-}

The environmental condition is degrading day by day making it difficult to live. The policy of CSR makes it compulsory for the Corporate to maintain the environmental condition. The CSR policy makes it compulsory for the Corporate to work towards the protection of environment.

\section{CSR in relation with Business components:-}

CSR can also be implemented within the business components such as:-

\section{Working Group:-}

Working group is the most important component of Business Enterprises. A worker who is employed in a factory or Business Enterprise or in a Corporate will not work only for the salary which is paid to him by the employer. With the help of CSR the Corporate can provide better living condition to the workers such as providing transportation, medical facility, scholarships to the children workers. After providing all these facility the worker will work for the benefit of the enterprise because he will be motivated by these facilities given to him by the Company or Corporate sector. Thus the worker will work for the success of the Organization. The worker and the employer will become one entity which will maximize profit and provide healthy environment to the company.

\section{Consumer:-}

The company should provide its quality service to his consumers. The consumer should satisfy with the services or the quality products produced by the company then only the company will survive in the long run.

\section{Suppliers of Raw Material:-}

Most of the transaction of the Business Enterprise or the company is done in credit basis so it is the duty to Corporate to make its payment to supplier and all other interest group on prescribed time. The supplier should provide best quality raw materials in an appropriate time resulting in best quality products.

\section{Government Organizations:-}

Various Government organization frame Rules and Regulations and Tax policies which need to be abiding by the organizations. If any of the company or organizations does not file returns on proper time then the organization has to face the consequences as prescribed under the law in terms of fines, penalties, imprisonments etc.

\section{Business Competitors:-}

If monopoly is existing in any Business Enterprise then there is no competition. The Business Enterprises must give healthy competition to its competitors by adopting fair trade practices. Thus the customer will get variety of good quality products with reasonable price. 


\section{Legal Provisions and CSR:-}

The companies which are having net worth of Rs 500 crore or more or turnover of Rs 1000 crore or more or net profit of Rs. 5crores or more then this company has to mandatory constitute CSR as per section 135 of companies act 2013. The CSR committee consists of three or more directors at least one is to be independent director. Board's reports shall disclose the composition of CSR committee. CSR committee will formulate CSR policy and recommend to the board a Corporate Social Responsibility. Policies which shall be indicated the activities to be undertaken by the company as per schedule VII i.e. activities which can be undertaken by companies as CSR. The committee has also to recommend the amount of expenditure to be incurred on the activities which are undertaken by the Corporate in CSR and should monitor the CSR policy. The board of every company after taking into account the recommendation made by CSR committee approve the CSR policy for the company and disclose the content of such policy in its reports and also on the company website. The board of shall ensure that the activity included in CSR policy the company are undertaken by the company. The company shall spend at least two percent of its average net profit made during the three immediate preceding financial Year in CSR. The company shall give preference to the local area where it is operating to undertake the activities of CSR. If company fails to spend on CSR then the board has to give reason why they have not spent the amount.

If a Company produces a wrong financial statement then it shall be punishable with a fine which shall not be less than fifty thousand Rupees but which may extend to twenty five lakh Rupees. Every officer of the company who is in default shall be punishable with an imprisonment for a term which may extend to three years or with fine which shall not be less than fifty thousand Rupees but which may extend to five lakh Rupees or with both.

Schedule VII of section 135 of Companies Act 2013:-

Activities which may be included by the Corporate in their CSR policy

1. Eradicating hunger poverty and malnutrition and sanitation which include contribution to Swatch Bharat Kosh setup by the central government for the promotion of sanitation.

2. Promoting education including special education and employment enhancing vocational skills among children, women, elderly people and differentially able and livelihood enhancing projects.

3. Promoting gender equality, empowering women by setting up hostel for women and orphans, setting up old age homes and day care centre for senior citizens and reducing inequality between Social economic backward groups.

4. Protection of environment and ensuring environment sustainability, ecological balance, flora and fauna, animal welfare, agro-forestry, conservation of natural resources and maintaining quality of soil, air and water including contribution to the clean Ganga fund set up by central government for rejuvenation of river Ganga.

5. Protection of natural heritage art and culture including restoration of buildings and sites of historical importance and work of art. Setting up public library, promotion and development of traditional arts.

6. Measures for the benefit of armed forces, veterans, war widows and their dependents.

7. Training to promote rural sports, nationally recognized sports, Paralympics sports and Olympic sports.

8. Contribution to Prime Ministers National Relief Fund or any other fund set up by central government for socio economic development and relief and welfare of the schedule casts, the schedule tribes, other backward classes, minorities and women.

9. Contributions or funds provided to technology incubators located within academic institutions which are approved by central government.

10. Slum area development.

\section{Conclusion:-}

In the course of running a Business, the Employer should not only work for the profit maximization, but also for the betterment of the workers which is the part of the society. Profit maximization remains the prime objective of the Corporate. In this process the Corporate should not neglect the society.

\section{References:-}

1. Pankaj Dodh, sarbjeet Singh and Ravita (2013), Corporate Social Responsibility and Sustainable Development in India, ISSN 2248-9878 vol. 3, pp. 681-688.

2. The companies Act 2013. 